\title{
Degana tungsten project-present plant practice and future scenario
}

\author{
M R JAKHU and S RAY \\ Hindustan Zinc Ltd, Yashad Bhavan, Udaipur 313001, India
}

\begin{abstract}
Experiments/testworks were carried out on Degana tungsten ore by various R \& D organizations to recover the strategic mineral wolframite. Process flowsheet developed after tests on the dump ore assaying $0 \cdot 151 \% \mathrm{WO}_{3}$ is being tried on a very small scale till the 150 tpd pilot beneficiation plant is commissioned. Tungsten bearing granite samples were also found amenable to physical beneficiation. Hence $168 \mathrm{Mt}$ granitic resources analysing $0.08 \%$ $\mathrm{WO}_{3}$ has ushered a hope for large scale exploitation subject to detailed exploration. By-product recovery of lithium, caesium, rubidium and some other trace elements, if feasible, will be of added advantage.
\end{abstract}

Keywords. Degana tungsten; present practice; future scenario.

\section{Introduction}

Degana Tungsten Project in Nagaur District (Rajasthan) is located midway between Jaipur and Jodhpur, and about $82 \mathrm{~km}$ from Ajmer by road. Since discovery in 1912, it was sporadically exploited by various agencies with peak operation during the world wars. The Directorate of Mines and Geology (DMG), Rajasthan, started its operation after the Indo-China war in 1962 . The operation continued subsequently by Rajasthan State Industrial and Mining Development Corporation (RSIMDC), Rajasthan State Mineral Development Corporation Ltd. (RSMDC) and Rajasthan State Tungsten Development Corporation Ltd. (RSTDC) by selective underground vein mining with concentration by manual sorting and panning. Due to low tenor and limited reserve, production from underground operation was limited and the beneficiation process was made exclusively manual. The activities were handed over to Hindustan Zinc Limited (HZL) w.e.f. 4.6.1991 with a view to large scale operation for strategic importance.

This paper deals with the activities of HZL towards tungsten development in Degana.

\section{Geology/mineralogy/characteristics}

Tungsten mineralization has been reported in: (1) granite vein lode, (2) eluvial deposit and (3) dissemination in phyllites.

Four decades of mining of wolframite was confined to underground mining on narrow 2 to $22 \mathrm{~cm}$ wide quartz wolframite veins in granite ground mass. Though beneficiation of eluvial and quartz vein type ore may be economically viable, known resources cannot sustain any large scale operation and underground exploitation will be cost prohibitive.

Though numerous thin quartz veins contain tungsten mineral (Bhatnagar 1991), their exploitation by underground method of mining is cost prohibitive. Exploration by RSTDC has indicated that the poorly mineralised granitic ground mass with their mineralised veins may make up the grade for open pit large scale exploitation. Four deep boreholes by the Mineral Development Board (MDB) and detailed surface 


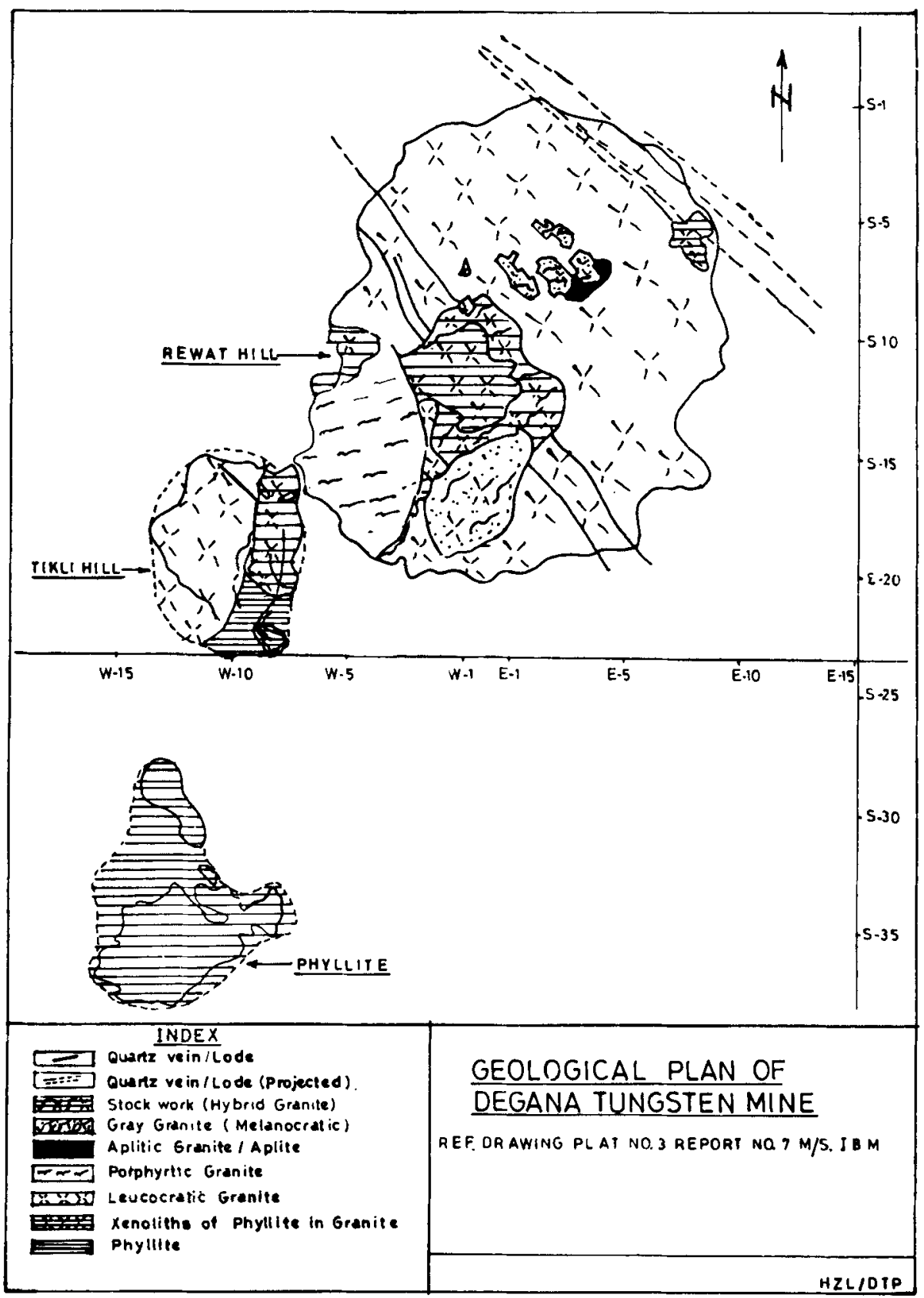

Figure 1.

mapping by the Indian Bureau of Mines (IBM), Nagpur have given further indication of potential ore deposits mineable by open cast. Orebody modelling conceptualized by HZL (Bhatnagar 1991) on stockwork (an admixture of all types of granites and a hybrid rock at the central part of the hill) (figure 1) suggest possibilities of $12-15 \mathrm{Mt}$ of ore with about $0 \cdot 13 \% \mathrm{WO}_{3}$. Accordingly exploration - (i) underground by $\mathrm{HZL}$ and (ii) surface 
by Mineral Exploration Corpn. Ltd. (MECL) - has been initiated. HZL has also initiated a pilot scale mining at $150 \mathrm{tpd}$ on the same zone from hill top. Waste rocks rejected from vein mining operations and manual sorting in the past have been found to assay $0 \cdot 151 \% \mathrm{WO}_{3}(\mathrm{IBM} 1990)$ and amenable to beneficiation. Presently beneficiation is confined to these waste dumps only.

\subsection{Ore resources/reserves of various loads}

Ore resources/reserves of various loads are summarized in table 1 (Report of 1988) and mineralogical analysis of the ore is given in table 2 . Wolframite is identified as the tungsten bearing mineral in the ore. A typical hand-picked pure wolframite sample analysed to have (BARC Report 1984):

\begin{tabular}{llrlll}
\hline $\mathrm{SiO}_{2}$ & $\ldots$ & $0 \cdot 24 \%$ & $\mathrm{MnO}$ & $\ldots$ & $10 \cdot 74 \%$ \\
$\mathrm{WO}_{3}$ & $\ldots$ & $72 \cdot 63 \%$ & $(\mathrm{Nb} / \mathrm{Ta})_{2} \mathrm{O}_{5}$ & $\ldots$ & $0.75 \%$ \\
$\mathrm{FeO}$ & $\ldots$ & $12 \cdot 29 \%$ & $\mathrm{TiO} 2$ & $\ldots$ & $0.05 \%$ \\
$\mathrm{Fe}_{2} \mathrm{O}_{3}$ & $\ldots$ & $1.89 \%$ & $\mathrm{CaO}$ & $\ldots$ & $0.42 \%$ \\
\hline
\end{tabular}

This corresponds to wolframite with Ferberite $\left(\mathrm{FeWO}_{4}\right)$ and Huebnerite $\left(\mathrm{MnWO}_{4}\right)$ ratio of $1: 1$.

Micro-indentation hardness of different grains vary between $\mathrm{VHN}_{100} 459-566$ with average of $\mathrm{VHN}_{100} 515$. Modes of occurrence with distinct grain sizes as observed are:

(a) Very coarse tabular crystals measuring up to $8 \mathrm{~mm}$ in size occurring in quartz veins.

(b) Coarse prismatic grains disseminated in granite, measuring in size between 150 and $500 \mu \mathrm{m}$.

(c) Smaller elongated prismatic crystals disseminated in aplite and granite. Rarely some of the crystals may be as long as $1 \mathrm{~mm}$ with a width of about $50 \mu \mathrm{m}$. Often aggregates of such crystals crowd quartz veins cutting across granite and aplite, the wolframite crystals in such cases generally project inwards from the border of veins.

(d) Aggregates of needle-shaped crystals, sometimes in the form of radiating rosette, disseminated in aplite veins.

Table 1. Reserve/resources (in million tonnes)

\begin{tabular}{|c|c|c|c|c|c|}
\hline & & $\begin{array}{l}\text { Ore reserves } \\
\text { (M.t.) }\end{array}$ & $\begin{array}{c}\mathrm{WO}_{3} \\
\%\end{array}$ & $\begin{array}{l}\text { Concentrate } \\
65 \% \mathrm{WO}_{3}(\mathrm{t})\end{array}$ & Source \\
\hline A: & $\begin{array}{l}\text { Vein type: } \\
\text { D, C, E \& F Lodes } \\
\text { Trench Lode }\end{array}$ & $\begin{array}{l}0.25 \\
0 \cdot 64\end{array}$ & $\begin{array}{l}0.28 \\
0 \cdot 12\end{array}$ & $\begin{array}{l}1088 \\
1158\end{array}$ & $\begin{array}{l}\text { IBM } \\
\text { RSTDC }\end{array}$ \\
\hline & Sub-total & 0.90 & $0 \cdot 17$ & 2274 & \\
\hline B: & $\begin{array}{l}\text { Trench lode wide zone } \\
\text { (granite) }\end{array}$ & $6 \cdot 17$ & $0 \cdot 13$ & 12340 & RSTDC \\
\hline $\mathrm{C}:$ & Gravel bed & $3 \cdot 35$ & 0.04 & 2062 & IBM/RSTDC \\
\hline D: & Stockwork (Phyllite) & $2 \cdot 70$ & 0.025 & 1038 & IBM/RSTDC \\
\hline E: & Granite resources & $168 \cdot 80$ & 0.086 & 223335 & RSTDC \\
\hline
\end{tabular}


Table 2. Mineralogical analysis of ore.

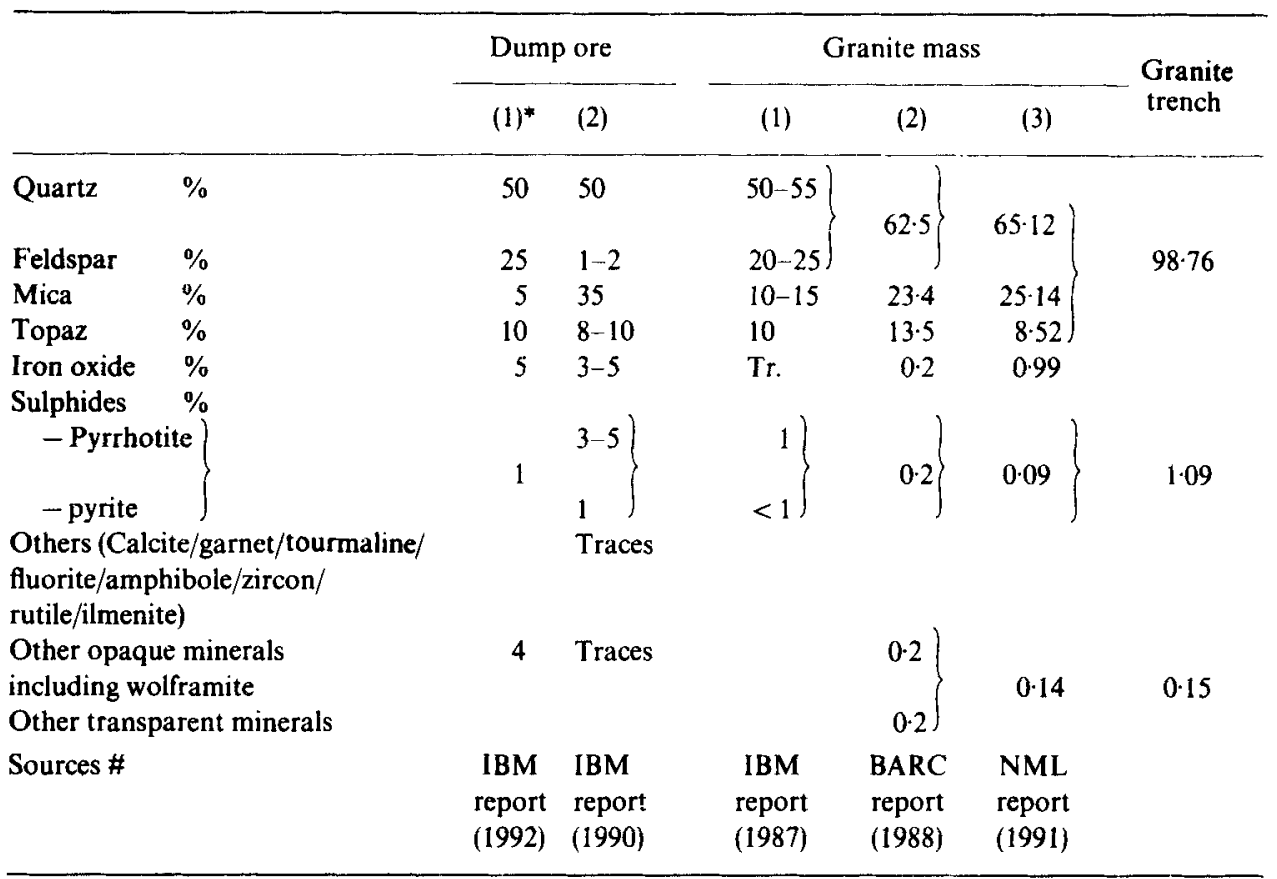

(Mica in granite is lithiferous (zinnwaldite)).

*Composite sample from dump ore are collected by HZL to pilot plant test by IBM (IBM/AJM/R 1-173)

\#Refer respective references.

(e) Short stubby crystals of variable size from about $50 \mu \mathrm{m}$ to about $250 \mu \mathrm{m}$ in quartz-topaz-muscovite veins cutting across granite. These are commonly associated with bismuthinite native bismuth composite grains.

(f) Very small nearly irregular crystals of size 10 to $50 \mu \mathrm{m}$ in fine-grained aplite veins. The wolframite grains are interstitial to quartz and felspar grains.

(g) As very narrow skeletal crystals occurring as inclusions in coarse quartz and mica (probably zinnwaldite). These crystals have a width of $5-10 \mu \mathrm{m}$ and length of upto $100 \mu \mathrm{m}$.

2.1a Sulphide assemblage (BARC Report 1984): This assemblage contains major pyrite and pyrrhotite, minor chalcopyrite, covellite, marcasite, sphalerite, bismuthinite, native bismuth and arsenopyrite and traces of molybdenite and stibnite. Native bismuth is commonly surrounded by bismuthinite and these two are often common associates of wolframite in quartz-topaz veins. Marcasite is finely intergrown with pyrite while chalcopyrite is often altered to covellite. Alteration of pyrite into a mixture of geothite and lepidocrocite (orthorhombic hydrous oxide of iron - $\mathrm{Fe}_{2} \mathrm{O}_{3} \cdot \mathrm{H}_{2} \mathrm{O} / \mathrm{a}$ dimorphous form of geothite) is very common, and this iron oxide reports with wolframite during magnetic separation affecting the grade of the wolframite concentrate. Emulsoid intergrowth of chalcopyrite in sphalerite is common. Interestingly no paragentic association of pyrite-pyrrhotite sulphide minerals with wolframite is noticed, hence composite particles between wolframite and sulphide minerals are never 


\begin{tabular}{|c|c|c|c|}
\hline & $\ddot{0}$ & 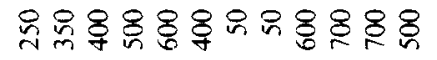 & 员号 \\
\hline & $\dot{a}$ & 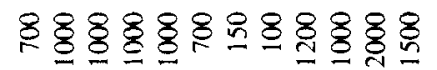 & $\underset{n}{8}$ \\
\hline & $\Xi$ & 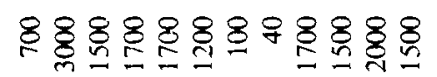 & 总总 \\
\hline & $\ddot{0}$ & 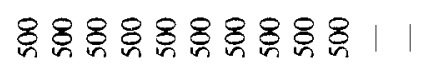 & 11 \\
\hline & $\Sigma$ & 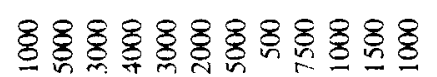 & 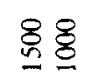 \\
\hline & $\grave{N}$ & 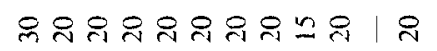 & $尺 1$ \\
\hline & $\ddot{n}$ & 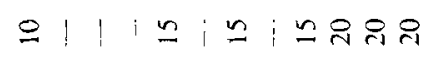 & 요 \\
\hline œ & 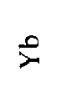 & 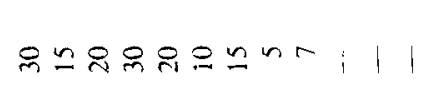 & 11 \\
\hline 5 & 2 & 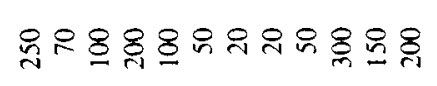 & \&్ల \\
\hline 造 & $\stackrel{3}{3}$ & $88.88 \Omega|1| g \mid$ & $1 \mid$ \\
\hline $\begin{array}{l}5 \\
0 \\
0 \\
0\end{array}$ & $\hat{z}$ & 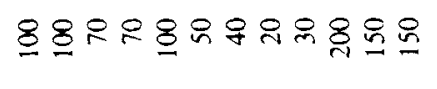 & 8 \\
\hline$\stackrel{\mathscr{E}}{\bar{E}}$ & $\bar{\infty}$ & 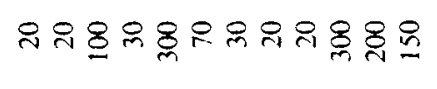 & 88 \\
\hline 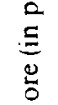 & $\mathscr{8}$ & 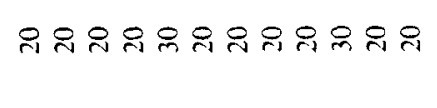 & 요 \\
\hline 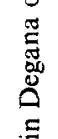 & 3 & 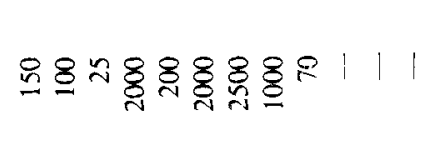 & $\stackrel{\infty}{\stackrel{\infty}{0}}$ \\
\hline 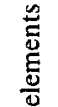 & $\tilde{n}$ & 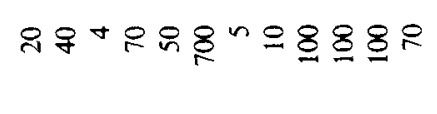 & 尺? \\
\hline 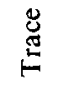 & $\stackrel{\circ}{\Sigma}$ & 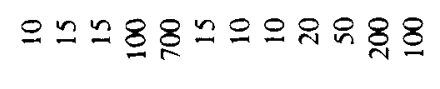 & 용요 \\
\hline$\dot{9}$ & ㄷ & $ళ_{i}|1|$ \& & 8 \\
\hline & $己$ & 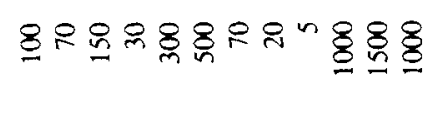 & $R \cap$ \\
\hline & $\dot{z}$ & 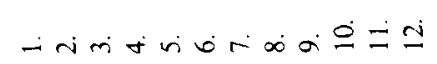 & \\
\hline
\end{tabular}


Table 4. Trace elements in Degana ore (in ppm) (from surface exploration) (Sood 1985-88).

\begin{tabular}{|c|c|c|c|c|c|c|}
\hline \multirow{2}{*}{$\begin{array}{l}\text { Sl. Sample description } \\
\text { no. }\end{array}$} & $\mathrm{Li}$ & $\mathrm{Rb}$ & Cs & w & \multirow[b]{2}{*}{$\mathrm{P} \%$} & \multirow[b]{2}{*}{$B(p p m)$} \\
\hline & \multicolumn{4}{|c|}{$(\mathrm{ppm})$} & & \\
\hline 1. Por. granite & 100 & 600 & 50 & 50 & 0.64 & 15 \\
\hline 2. Por. granite & 125 & 500 & 50 & 50 & 0.85 & 15 \\
\hline 3. Por. granite & 500 & 600 & 50 & 75 & 1.65 & 15 \\
\hline 4. Por granite & 275 & 400 & 50 & 75 & 0.97 & 15 \\
\hline 5. Grey granite \& mica & 800 & 600 & 50 & 350 & $2 \cdot 20$ & 10 \\
\hline 6. Por. granite \& mica & 700 & 700 & 50 & 150 & $2 \cdot 10$ & 10 \\
\hline 7. Grey granite \& mica & 900 & 800 & 50 & 900 & $1 \cdot 28$ & 15 \\
\hline 8. Granite & 25 & 300 & 50 & 150 & 0.54 & 15 \\
\hline 9. Granite & 200 & 500 & 50 & 200 & 0.92 & 15 \\
\hline 10. Granite \& mica & 225 & 600 & 50 & 75 & $0 \cdot 73$ & 15 \\
\hline 11. Grey granite with mica & $0 \cdot 14 \%$ & 900 & 50 & 300 & $1 \cdot 74$ & 10 \\
\hline 12. Quartz-mica veins & $0.24 \%$ & $0.18 \%$ & 50 & 75 & $1 \cdot 50$ & 10 \\
\hline $\begin{array}{l}\text { 13. Granite with lot of mica } \\
\text { \& fluorite (?) }\end{array}$ & $0 \cdot 16 \%$ & $0 \cdot 19 \%$ & 50 & $0 \cdot 18 \%$ & 1.67 & 10 \\
\hline 14. Mica of quartz-mica veins & $0 \cdot 20 \%$ & $0 \cdot 27 \%$ & 50 & 800 & $1 \cdot 20$ & 10 \\
\hline $\begin{array}{l}\text { 15. Granite with aplite } \\
\text { pebble \& mica }\end{array}$ & 900 & 700 & 50 & 900 & $0 \cdot 34$ & 10 \\
\hline 16. Mica \& quartz veins & $0.53 \%$ & $0.67 \%$ & 90 & $0 \cdot 14 \%$ & 0.98 & 10 \\
\hline 17. Granite and mica & 600 & 700 & 50 & 100 & $0 \cdot 36$ & 15 \\
\hline 18. - do- & 300 & 600 & 50 & 175 & 0.64 & 15 \\
\hline 19. Granite & 150 & 160 & 50 & 250 & 0.91 & 15 \\
\hline $\begin{array}{l}\text { 20. Grey granite with quartz } \\
\text { veins }\end{array}$ & $0 \cdot 22 \%$ & 800 & 50 & 500 & 0.91 & 15 \\
\hline 21. Quartz mica veins & $0 \cdot 26 \%$ & $0 \cdot 50 \%$ & 70 & 350 & 0.40 & 15 \\
\hline 22. Grey granite & $0 \cdot 26 \%$ & 900 & 50 & 450 & $1 \cdot 15$ & 10 \\
\hline 23. Granite & 400 & 400 & 50 & 300 & $1 \cdot 24$ & 10 \\
\hline $\begin{array}{l}\text { 24. Por. granite with } \\
\text { veins with mica }\end{array}$ & $0.15 \%$ & 800 & 50 & 150 & 0.95 & 10 \\
\hline 25. Quartz veins with mica & $0 \cdot 43 \%$ & $0.91 \%$ & 100 & 150 & 1.63 & 10 \\
\hline 26. Breccia zone & 600 & 500 & 50 & 150 & 0.66 & 15 \\
\hline 27. Granite porphyry & 150 & 400 & 50 & 50 & 0.36 & 15 \\
\hline 28. -do- & 75 & 300 & 50 & 50 & 0.07 & 15 \\
\hline 29. Grey granite with plenty of mica & $0 \cdot 10 \%$ & 700 & 50 & 50 & 0.97 & 40 \\
\hline 30. Granite & 500 & 500 & 50 & 200 & 0.50 & 10 \\
\hline 31. Granite with thin mica veins & $0 \cdot 11 \%$ & 800 & 50 & 150 & 1.85 & 10 \\
\hline 32. Granite & 800 & 600 & 50 & 200 & 0.61 & 10 \\
\hline 33. Granite with quartz mica & $0 \cdot 10 \%$ & 700 & 50 & $0.90 \%$ & 0.76 & 10 \\
\hline 34. Breciated zone & 600 & 600 & 50 & 300 & 0.67 & 10 \\
\hline 35. Grey granite \& micaceous veins & $0.12 \%$ & 700 & 50 & 50 & 0.86 & 10 \\
\hline 36. Grey granite & 800 & 600 & 50 & 350 & 0.95 & 10 \\
\hline 37. Quartz + mica veins & $0.13 \%$ & $0.22 \%$ & 50 & $1 \cdot 60$ & 1.00 & 10 \\
\hline 38. Mica content only & $0.12 \%$ & 600 & 50 & 0.55 & $1 \cdot 10$ & 10 \\
\hline $\begin{array}{l}\text { 39. Breccia zone (granite } \\
\text { pebbles \& micaceous matrix) }\end{array}$ & $0.62 \%$ & $0 \cdot 89 \%$ & 75 & 50 & 0.76 & 10 \\
\hline 40. Granite pebbles of breccia zone & $0 \cdot 12 \%$ & 500 & 50 & 600 & 0.36 & 10 \\
\hline 41. Breccia zone & 250 & 500 & 50 & 200 & 0.60 & 10 \\
\hline 42. Granite porphyry & $0 \cdot 10 \%$ & 500 & 50 & 150 & 0.72 & 10 \\
\hline 43. Granite with dark material & 125 & 250 & 50 & 50 & $0 \cdot 13$ & 10 \\
\hline 44. Granite with mica & 600 & 700 & 50 & 50 & 0.43 & 10 \\
\hline
\end{tabular}


Table 4. (Continued)

\begin{tabular}{|c|c|c|c|c|c|c|}
\hline \multirow{2}{*}{$\begin{array}{l}\text { Sl. Sample description } \\
\text { no. }\end{array}$} & $\mathrm{Ll}_{\mathrm{l}}$ & $\mathrm{Rb}$ & $C s$ & W & & \\
\hline & \multicolumn{4}{|c|}{ (ppm) } & $\mathrm{P} \%$ & $\mathrm{~B}(\mathrm{ppm})$ \\
\hline 45. Granite porphyry & 450 & 600 & 50 & $0.20 \%$ & 0.58 & 10 \\
\hline 46. Granite porphyry & 150 & 350 & 50 & 100 & $0 \cdot 34$ & 10 \\
\hline 47. Granite porphyry & 250 & 500 & 50 & 75 & 0.56 & 10 \\
\hline 48. Grey granıte & 250 & 400 & 50 & 150 & 0.46 & 10 \\
\hline 49. Grey granite \& mica & 300 & 500 & 50 & 75 & $0 \cdot 34$ & 10 \\
\hline 50. Por granite with mica & $0 \cdot 10 \%$ & 700 & 50 & 50 & 1.02 & 10 \\
\hline 51. Mica quartz veins & 700 & 600 & 50 & 75 & 1.07 & 10 \\
\hline 52. Grey granite + mica & $0.16 \%$ & $0.25 \%$ & 80 & 75 & 1.80 & 10 \\
\hline 53. Grey granite + mica & $0 \cdot 14 \%$ & 800 & 60 & 50 & $0 \cdot 35$ & 10 \\
\hline
\end{tabular}

observed. The only sulphide association of wolframite is bismuthinite-native bismuth composites.

2.1b Oxide minerals (BARC Report 1984): Magnetite, ilmenite, hematite, geothite and lepidocrocite are the main oxide minerals. Traces of cassiterite are also noticed. Magnetite being strongly paramagnetic is readily separated from wolframite during magnetic separation. After pyrite, geothite and lepidocrocite are paramagnetic and report with wolframite during magnetic separation. At some places, the mineral has been altered insignificantly to scheelite $\left(\mathrm{CaWO}_{4}\right)$. Samples from (MDB) bore holes taken during exploration by RSTDC and analysed by the Bhabha Atomic Research Centre (BARC) showed presence of various trace elements in the Rewat granite hill (Degana) (Report of 1988) (table 3). Field investigation (Sood 1985 88) by the Geological Survey of India (GSI) for lithium in Gujarat and Rajasthan reported presence of trace elements in Degana ore (table 4).

\subsection{Liberation}

The trimodal distribution of wolframite grains occur as observed (IBM Report 1987; Rao et al 1987): (a) Coarse crystals of 2 to $8 \mathrm{~mm}$ size, (b) medium size crystals and aggregate crystals in $50 \mu \mathrm{m}-250 \mu \mathrm{m}$ sizes and (c) very fine sized skeletal crystals of $10-25 \mu \mathrm{m}$ which occurs as inclusions in quartz, mica and topaz.

In general, first two categories account for about $90 \%$ of $\mathrm{WO}_{3}$ distribution. Occurrence of wolframite is found to be more disseminated in the trench lode granite. In general test work suggests $80 \%$ liberation of wolframite at $-400 \mu \mathrm{m}$ (35 mesh) grinding for pre-concentrate.

\section{Beneficiation at Degana}

HZL has initiated installation of a 150 tpd pilot plant based on IBM flowsheets on dump ore. The beneficiation by manual panning ceased in preference to mechanised system just prior to takeover by HZL. Meanwhile in the interim period, some equipments have been mobilised from other units for continued testwork on grinding, tabling as well as familiarisation of the equipments/process to the staff to be deployed. 


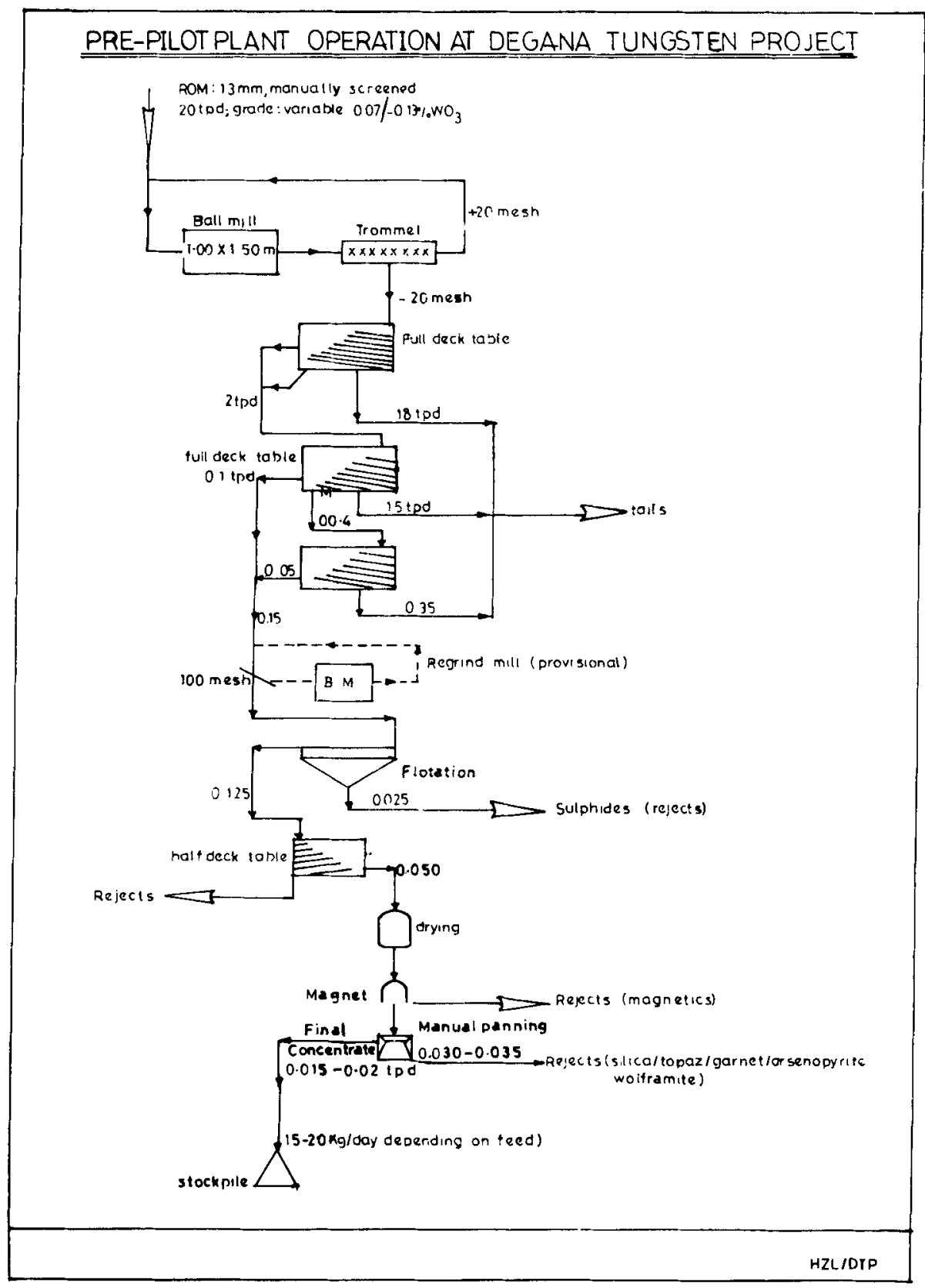

Figure 2.

\subsection{Present beneficiation practice}

Against sp. gr. of 2.7-3.3 for gangue minerals, the sp. gr. of 7.3 for wolframite suggests wet gravity separation as the most appropriate one. Brittleness of wolframite against hard quartz/granite dictates coarse narrow range grinding such as rod milling for optimal mineral liberation without significant losses by overgrinding. Eighty per cent 
liberation of wolframite can be achieved at $-400 \mu$ (35 mesh) grinding. These basic principles are adopted on the processes adapted for obtaining preconcentrate/rough concentrate.

Manually screened $-13 \mathrm{~mm}$ dump ore is fed to one $1.0 \mathrm{~m}$ dia $\times 1.5 \mathrm{~m}$ Sala Rubber Roller (SRR) ball mill in close circuit with a trommel of $0.8 \mathrm{~mm}$ (20\#) opening (figure 2). The pre-concentrate from standard concentrating table $(1.8 \mathrm{~m} \times 4.5 \mathrm{~m})$ goes for regrinding at $150 \mu(100 \#)$. The material after conditioning with xanthate and frother (MIBK) is fed to one self-aerated flotation cell. The sulphides (froth) are continuously removed till their generation seizes to appear. The tails from the flotation go to table (half size) concentration. The clean concentrate now obtained is dried and further upgraded from highly magnetics with the help of permanent bar-magnet. Non-magnetics (silica, topaz, garnet etc.) are moved by manual panning.

The mineralogical and petrological studies (Roy 1991) on typical samples shows that: (a) in sulphide floats (rejects), liberated mineral accounts for around $97 \%$ (pyrite over $88 \%$ ) and rest being pyrrhotite, chalcopyrite, wolframite and other gangue minerals and (b) in magnetic rejects, liberated mineral accounts for $95 \%$, ilmenite being the principal constituent accounts for about $80 \%$. Others are wolframite, pyrite, pyrrhotite, chalcopyrite, molybdenite, cassiterite, etc.

The product is stockpiled only after analytical confirmation (DMRL Report 1987) to meet the grade, e.g. $\mathrm{WO}_{3}->65 \% ; \mathrm{Mo}-<0.1 \%$; $\mathrm{SiO}_{2} / \mathrm{Bi} / \mathrm{S} / \mathrm{F} /\left(\mathrm{Ca}+\mathrm{SiO}_{2}\right)$ each $-<1.0 \% ; \mathrm{As} / \mathrm{Sn} / \mathrm{P}$ each $-<0.05 \% ; \mathrm{Cu}-<0.5 \% ; \mathrm{Ca}-<0.2 \%$.

\subsection{Observation}

(i) Brackish water as available at site does not affect physical beneficiation.

(ii) Significant losses are reported due to overgrinding in the ball mill. Under consultation with the manufacturer Trelleborg/SALA, these SRR ball mills got converted into SRR rod mills to get the desired grinding. These SRR rod mills are to be used in regrinding circuit of the 150 tpd plant.

(iii) Due to absence of analytical facilities at site at present, mass balance, grade etc. cannot be ascertained. Hence tails/slimes are stored for reprocessing in future. Analytical laboratory facilities are now incorporated in the 150 tpd plant.

(iv) Regrinding was very limited and was carried out by roll crusher only. This is due to fairly liberated grains in finer fraction of the dump. Detailed sampling (IBM Report 1990) showed about $56 \%$ of $\mathrm{WO}_{3}$ distributed in $-13 \mathrm{~mm}$ fraction of the dump which constituted about $34 \%$ of the dump.

(v) Present drying process (sun drier/hot plate) will not be adequate for 150 tpd plant where dry high intensity magnetic separator will be adopted.

\subsection{Operations in the plant}

One 150 tpd plant under construction will treat primarily the dump ore to produce concentrates of the desired grade and generate design data for commercial plant while optimizing recovery. Based on the flowsheet (figure 3) suggested by IBM on bench scale test (IBM/AJM/RI-127), the process flowsheet as developed by HZL is shown in figure 4. The operations suggested in the plant will be: 
(A) Crushing-screening module of existing SALA CARAVAN Mill in HZL will operate 2 shift/day basis. The settings of jaw crusher and hydrocone crusher are to be adjusted for $-15 \mathrm{~mm}$ screened product against original $-6 \mathrm{~mm}$ product for ball mill feed.

(B) In the milling circuit, operating 3 shift/day basis, one rod mill $(1.8 \mathrm{~m} \mathrm{dia} \times 3.3 \mathrm{~m})$ will grind the ore to $-417 \mu \mathrm{m}(-35 \mathrm{mesh})$ in close circuit. The rod mill discharge

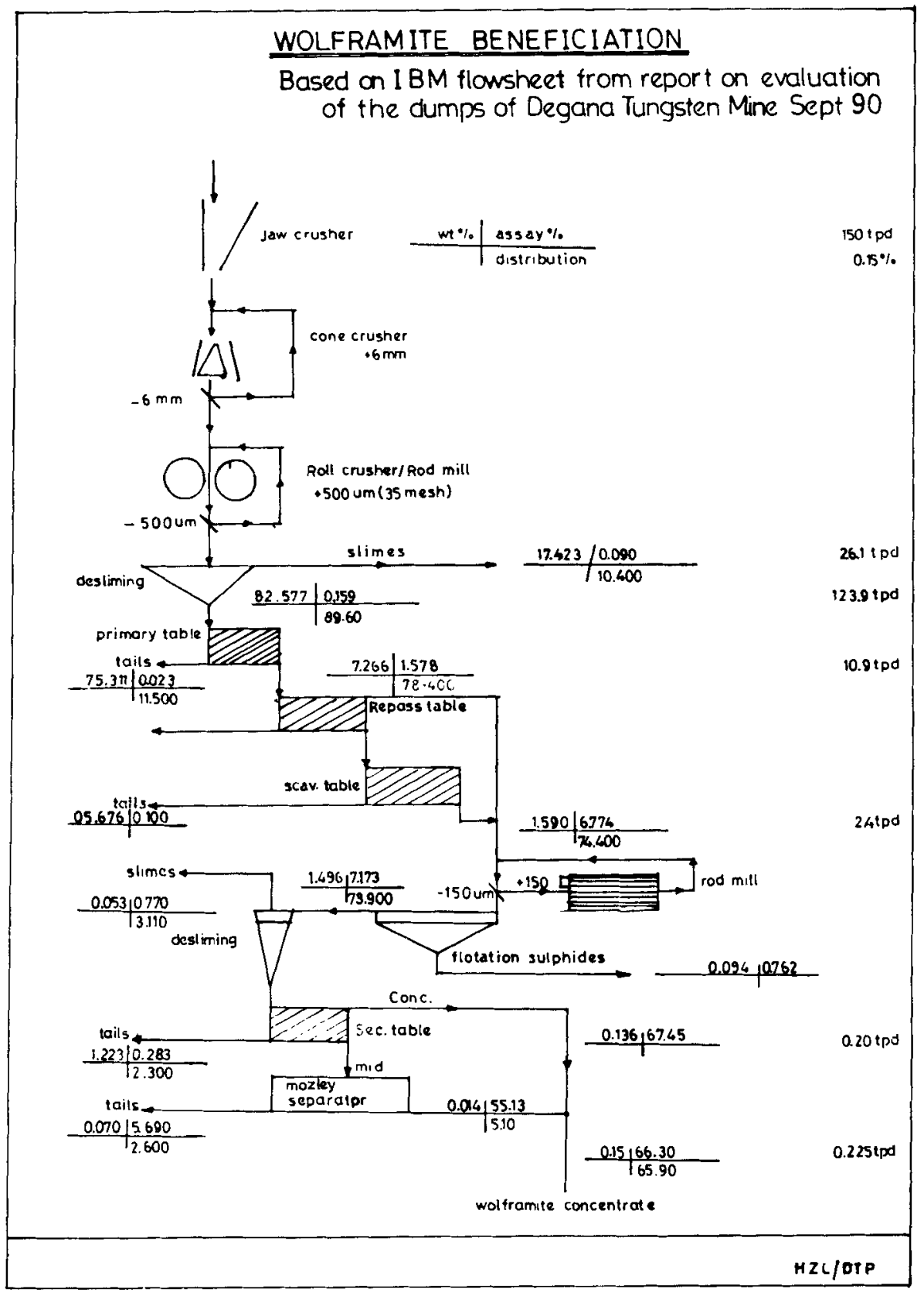

Figure 3. 


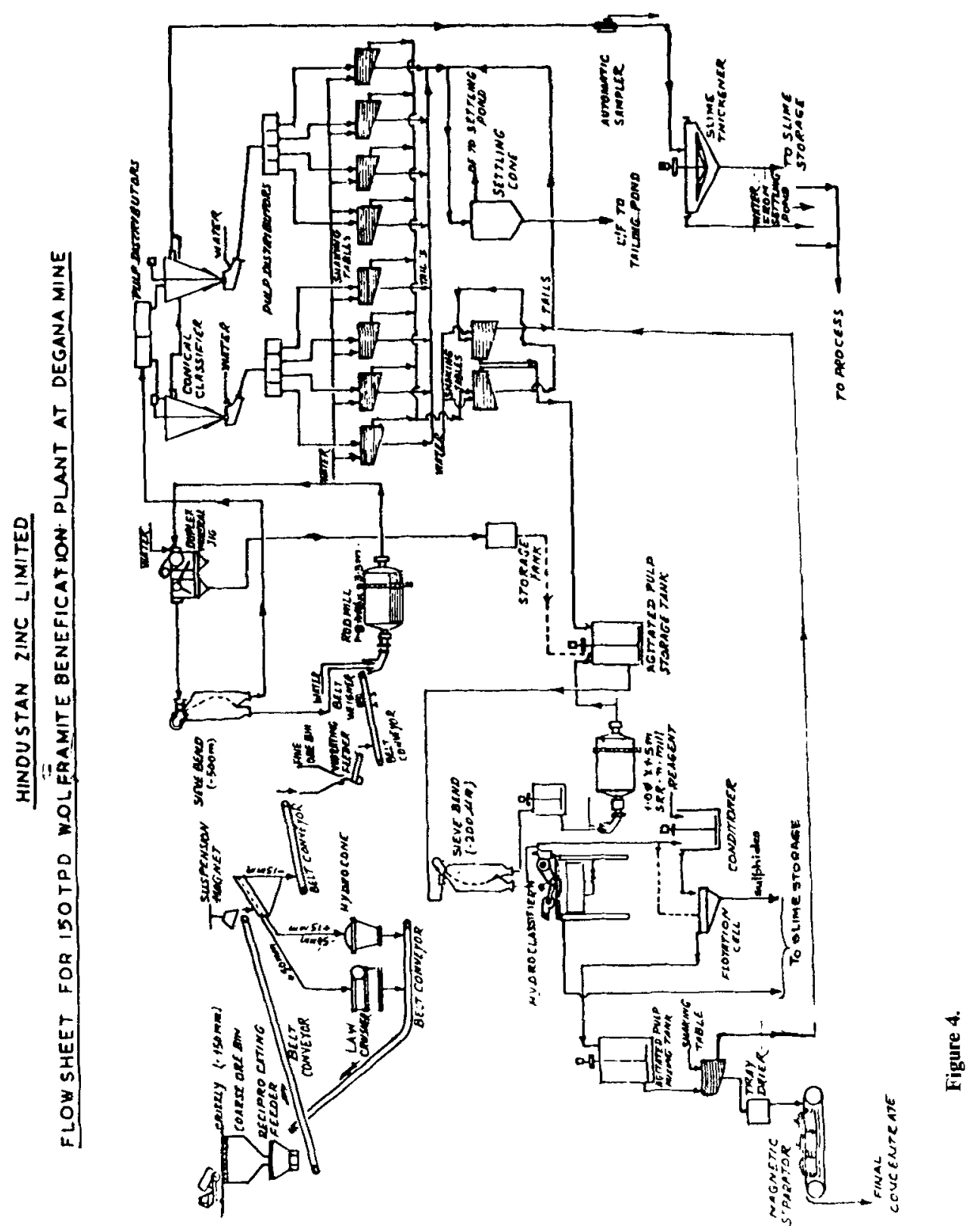


Table 5. Comparison of IBM test results.

\begin{tabular}{|c|c|c|c|}
\hline \multirow[b]{2}{*}{ Items } & \multicolumn{3}{|c|}{ Low grade composite dump sample } \\
\hline & \multicolumn{2}{|c|}{$\begin{array}{c}\text { Present work } \\
\text { IBM/AJM/RJ-173 }\end{array}$} & \multirow{2}{*}{$\begin{array}{c}\begin{array}{c}\text { Earlier work } \\
\text { IBM/AJM/RI-127 }\end{array} \\
\begin{array}{c}\text { Tech. Cons. of } \\
\text { IBM. Nagpur }\end{array}\end{array}$} \\
\hline 1. Sample drawn by & HZL Degana & & \\
\hline 2. Feed assay & $0.134 \% \mathrm{WO}_{3}$ & & $0.151 \% \mathrm{WO}_{3}$ \\
\hline \multirow{5}{*}{$\begin{array}{l}\text { 3. Mineralogy } \\
\text { (approx.) }\end{array}$} & Quartz & $50 \%$ & $50 \%$ \\
\hline & Mica & $5 \%$ & $35 \%$ \\
\hline & Topaz & $10 \%$ & $8-10 \%$ \\
\hline & Iron oxide & $5 \%$ & $3-5 \%$ \\
\hline & Feldspar & $25 \%$ & $1-2 \%$ \\
\hline $\begin{array}{l}\text { 4. Wolframite grains } \\
\text { size }\end{array}$ & 0.02 to $0.2 \mathrm{~mm}$ & & 0.18 to $0.54 \mathrm{~mm}$ \\
\hline $\begin{array}{l}\text { 5. Beneficiation pro- } \\
\text { cess attempted }\end{array}$ & Identical & & Identical \\
\hline \multirow{3}{*}{$\begin{array}{l}\text { 6. Final concentrate } \\
\text { produced }\end{array}$} & Wt.\% & $0 \cdot 120$ & 0.150 \\
\hline & Assay $\left(\% \mathrm{WO}_{3}\right)$ & $66 \cdot 51$ & $66 \cdot 30$ \\
\hline & Dist $\left(\% \mathrm{WO}_{3}\right)^{3}$ & $59 \cdot 8$ & $65 \cdot 9$ \\
\hline \multirow{3}{*}{$\begin{array}{l}\text { 7. Low grade conc. } \\
\text { (Mozley tails) }\end{array}$} & $\mathrm{WO}_{3} \%$ & $0 \cdot 273$ & $1 \cdot 223$ \\
\hline & Assay $\% \mathrm{WO}_{3}$ & $3 \cdot 520$ & 0.283 \\
\hline & Dis. $\left(\% \mathrm{WO}_{3}\right)^{3}$ & $7 \cdot 200$ & $2 \cdot 30$ \\
\hline
\end{tabular}

will pass through a mineral jig for recovery of coarse liberated wolframite, before screening in a sieve bend. Sieve bend has been selected in preference to hydrocyclone, to screen heavy undersize wolframite particles to avoid recirculation and losses in regrinding. Underflow goes to cone classifier for removal of slime (about $15 \%$ by weight) which will be stockpiled to treat by a different route under development. Classifier underflow goes for pre-concentration by 8 nos. standard concentrating table and gets cleaned by 2 nos. concentrating table. The clean table-concentrate and jig underflow go to agitated storage tank while tails go to dam.

(C) In the final upgrading circuit, operating on one shift basis, the pre-concentrate will be reground to $208 \mu \mathrm{m}(65 \mathrm{mesh}) / 150 \mu \mathrm{m}$ (100 mesh) in close circuit with a sieve bend. While the fines/slime from hydroclassifier is removed/stored, the underflow goes to sulphide separation by froth flotation; the flotation cell underflow/tails goes to table concentration. The concentrate, after drying in tray drier system, will be subjected to high intensity magnetic separator (HIMS) for separation of wolframite.

Water is scarce in Rajasthan, therefore, in the above process, water reclamation has been made from tailing, slime thickner etc. Once the system stabilizes, recovery of wolframite and byproducts (lithia-mica and trace elements) will be attempted. In continuation of earlier testwork (IBM/AJM/RI-173) on bench scale test, IBM has recently re-confirmed (IBM/AJM/RI-173) about recovery and product grade on the pilot plant operation of the dump ore conducted at Ajmer and the pre-pilot plant operation at Degana. A comparison is shown in table 5. 


\section{WOLFRAMITE BENEFICIATION}

Based on I BM flowsheet for Beneficiation of Granite Rock (Aef-Report IB M/ASM/A1-85 Dated NOV-B7)

$1000 \operatorname{tpd}$

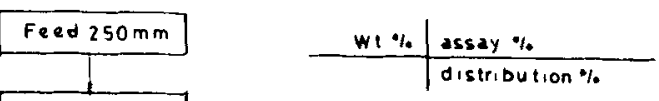

Jaw Crusher
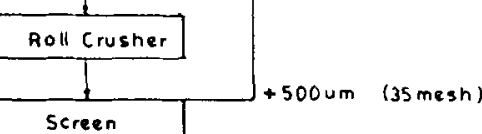

-

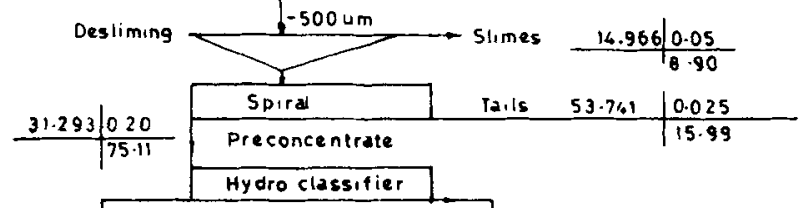

313100 Hydro classifier

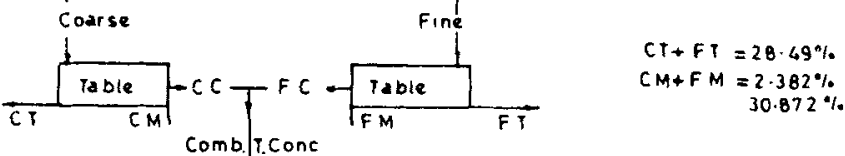

$4.2 t p d$

Comb.r.conc $30.872 \%$
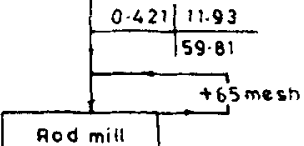

POd mill

-65 mesh

1.36 tpd

$\begin{array}{lll}0.136 & 0.37\end{array}$

$\frac{0.37}{10.60}$

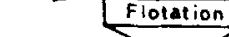

Non sulphides

$\frac{0.285}{17.45}$

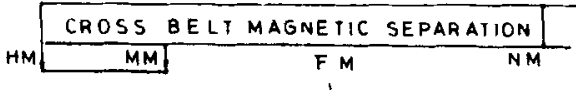

$0.94 \mathrm{tpd}$

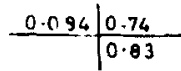

I

Wolframite Concentrate

$0.670 \mathrm{ipd}$

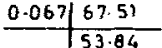

Figure 5.

\section{Future scenario}

\section{$4.1 I B M$}

IBM has also conducted beneficiation test (IBM/AJM/RI-85) on granitic ore from Degana and a flowsheet (figure 5), only for recovery of wolframite, has been suggested. 


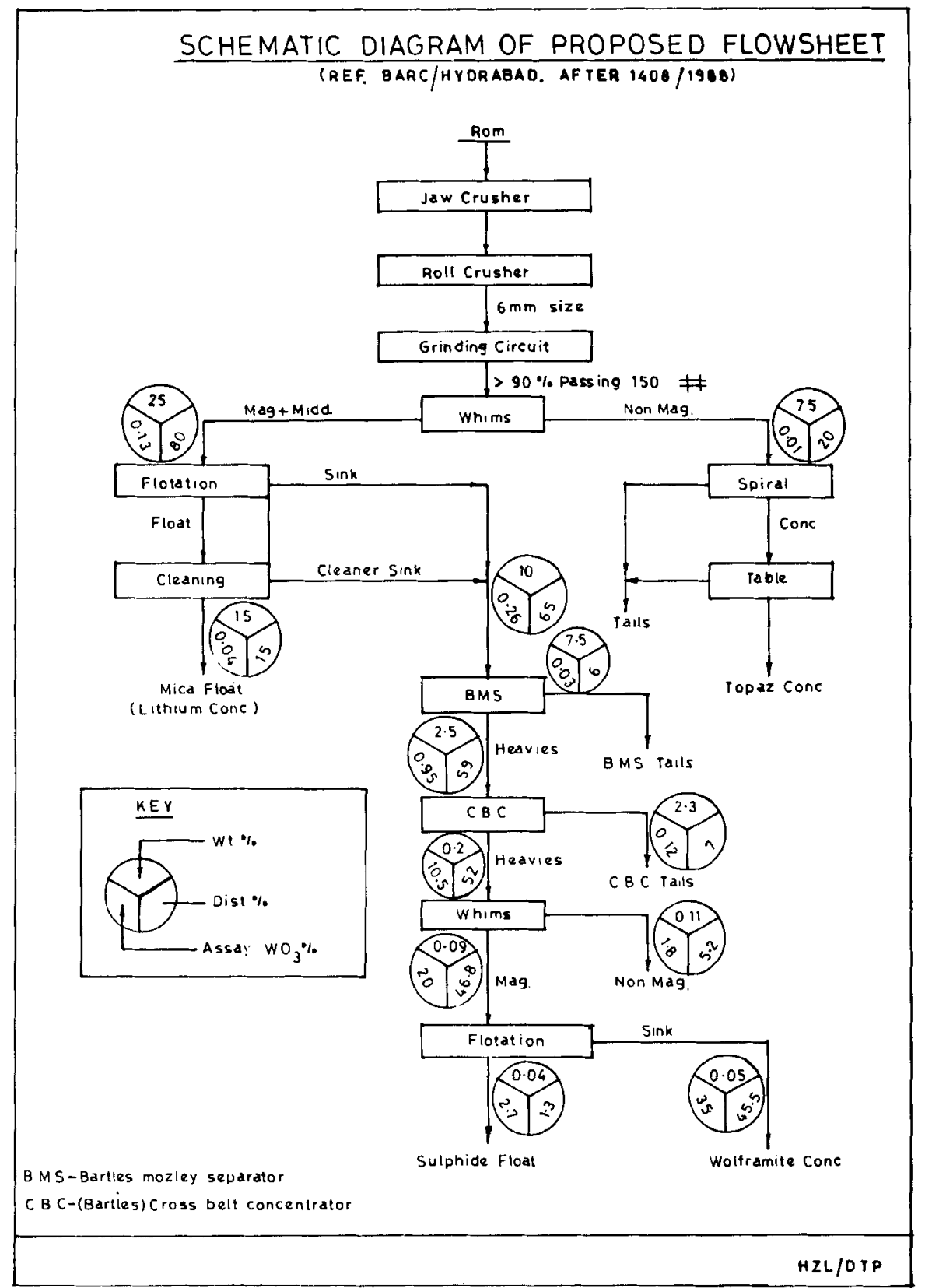

Figure 6.

The flowsheet, which slightly differs from that for dump ore, incorporates hydrocyclone for desliming and spiral for ore-concentration prior to tabling.

They have also been engaged in technical consultancy for: (a) stabilizing the process in 150 tpd plant, (b) related test work towards identification of lithium and other associated trace elements and possible recovery as byproducts and (c) augmentation of 
the plant to 300 tpd for treating dump/granitic ore with minimum investment on major equipments in the existing plant.

\section{$4.2 B A R C$}

BARC has also carried out laboratory investigations on recovery of wolframite from low grade granite type ore from Degana (Rao et al 1987; BARC Report 1988). This test work as well as the flowsheet developed (figure 6) is unique and differs from earlier investigations on tungsten beneficiation by BARC and other agencies. The process flowsheet considers tungsten recovery with byproduct recovery of lithium and topaz. Better viability has been suggested at $0.1 \% \mathrm{WO}_{3}$ of the granite ore. The granite sample analysed $0.23 \% \mathrm{Li}_{2} \mathrm{O}$ and an average of $0.15 \% \mathrm{Li}_{2} \mathrm{O}$ has been suggested for entire granite mass. Granite samples from various parts analysed to contain $\mathrm{Li}_{2} \mathrm{O}$ varying from $0.111 \%$ to $0.284 \%$ with highest incidence at $1.4 \%$ in mica vein. The ore is ground to $-100 \mu \mathrm{m}(-150 \mathrm{mesh})$ and then is subjected to wet high intensity magnetic separation (WHIMS) at $15 \mathrm{k}$. Gauss when wolframite and mica rich magnetics separate out, topaz is recovered from nonmagnetic tails by spiral followed by tabling. Mica (Zinnwaldite, lithium rich) is separated by froth flotation followed by cleaning with magnetic separator to give $1 \cdot 0-1 \cdot 1 \% \mathrm{Li}_{2} \mathrm{O}$ with recovery at $50-60 \%$. For example a 1000 tpd plant may yield a recoverable lithia in concentrate at about 450 tonnes annually. Magnetic susceptibility of mica concentrate was also reported to vary with $\mathrm{Li}_{2} \mathrm{O}$ content. The tails go for wolframite concentration by Bartles-Mozley-Separator (BMS), Bartles Cross Belt Concentrator (CBC), (WHIMS) and lastly by reverse flotation. Since BMS and CBC are effective in recovering heavy particles down to $10 \mu \mathrm{m}$, the loss of fines are less. During this test work on granite with very low tungsten values $\left(0.04 \% \mathrm{WO}_{3}\right)$, it was observed that about $21 \%$ wolframite remains unliberated even at the grind size of -100 microns. It is estimated that $8 \%$ is interlocked with quartz/granite, $4 \%$ is interlocked with mica and $9 \%$ is interlocked with topaz. BARC has expressed confidence in developing processing scheme for extraction of lithium from lithia mica and also for conversion of topaz into mullite. HZL is considering to take up these as R\&D activity. In a recent communication BARC have indicated the mica sample from Degana to contain $0.53 \% \mathrm{Rb}$ and $0.27 \% \mathrm{Cs}$. This information has given more importance to detailed exploration and by-product recovery from Degana ore.

\subsection{National Metallurgical Laboratory, Jamshedpur}

NML, a premier nation.ll scientific organization in metallurgical field, has been entrusted as the nodal agency by Defence Research and Development Organization (DRDO) for evaluation of process flowsheets along with the development of beneficiation technology for all indigenous tungsten resources (PMCTD). It is envisaged that the flowsheet evolved by NML would be transferred to HZL for large scale production (PMCTD 1990).

Testwork have been carried out on various types of ore, preconcentrate, jig concentrate etc. NML in general suggests physical beneficiation (NML Report 1991; PMCTD) to $10-30 \% \mathrm{WO}_{3}$ followed by chemical beneficiation to APT (ammonium paratungstate: $5\left(\mathrm{NH}_{4}\right)_{2} \mathrm{O} \cdot 12 \mathrm{WO}_{3}$ ) to be most promising economic route for the low tenor tungsten bearing granite. 
The trench load granite in the northern sector is of difficult metallurgical grade. The test work on this granite by NML yielded best value at $-100 \mu$ grinding, vanning followed by magnetic separation, a concentrate assaying $5.86 \% \mathrm{WO}_{3}$ with weight recovery of $0.3 \%$ and distribution at $37.7 \%$.

$\mathrm{HZL}$ has sent 10 tonnes of granite sample from Rewat hill top (proposed zone for mining) to NML and 1.0 tonne to IBM. IBM has recently indicated following results (IBM/AJM/R 1-157) by gravity concentration:

Feed grade: Granite ore with $0 \cdot 08 \% \mathrm{WO}_{3}$

\begin{tabular}{lcc}
\hline Percentage & $\begin{array}{c}\text { Final } \\
\text { concentrate }\end{array}$ & $\begin{array}{c}\text { Low grade } \\
\text { concentrate }\end{array}$ \\
\hline Grade, WO $_{3}$ & 65.65 & 40.0 \\
Weight recovery & 0.07 & 0.018 \\
$\mathrm{WO}_{3}$ distribution & 56.10 & 8.80 \\
\hline
\end{tabular}

Another lot of freshly blasted granitic ore from underground, about $50 \mathrm{~m}$ below surface, crushed to $-13 \mathrm{~mm}$ was sent to NML. It assayed at $0 \cdot 2 \% \mathrm{WO}_{3}$. Complete report on these test works along with physical and chemical beneficiation is awaited.

\subsection{Tata Research Development and Design Centre, Pune}

This organization had carried out studies on recovery of tungsten values from slimes generated at Degana and those produced during the test work conducted by BARC on the granite ore assaying $0.04-0.05 \% \mathrm{WO}_{3}$. About $50-60 \%$ of $\mathrm{WO}_{3}$ is lost in tailing (Tata Research Development and Design Centre Report 1991) and any method to recover some from tailing will be value added operation. The test work involving flotation of slimes has given encouraging results. These findings need to be further confirmed by conducting testwork on the slimes generated during the proposed 150 tpd plant.

\section{Conclusion}

If the exploration initiated is successful, the quality and quantity of the ore will significantly improve rendering large scale operation economically viable. The selected process in some combination of processes described may achieve high recovery to be split into a high grade wolframite concentrate as per the Defence Metallurgical Research Laboratory (DMRL) specification (DMRL Report 1987) and a significant quantity of middling (low grade) for APT process.

The thrust has been given by HZL on R\&D activities for identifying and recovery of trace elements. The viability is expected to improve significantly with recovery of trace elements like lithium, yttrium, caesium, rubidium, etc.

\section{Acknowledgement}

The authors are grateful to Shri A C Wadhawan, Chairman-Managing Director and Shri H V Paliwal, Director (Mining Operations), Hindustan Zinc Limited, for their kind support. 


\section{References}

BARC/Hyderabad 1984 Beneficiation of Wolframite ore from Degana, Rajasthan

DMRL/Hyderabad 1987 Development of tungsten resource management

IBM Report 1987 Beneficiation of granite rock for recovery of tungsten from Degana tungsten, IBM/Ajmer/R I-85

BARC/Hyderabad 1988 Laboratory investigations on recovery of wolframite from low grade granite type of ore from Degana, Rajasthan (1408/1988)

Rao N K, Manmadha M and Sukla S K 1987 Studies on beneficiation of low grade wolframite ore from Degana, Rajasthan. Paper presented at the national workshop on tungsten reserves

Sood N K 1985-88 A report on the investigation for lithium mineralization in Rajasthan and Gujarat (final report for field sessions $1985-88$ )

Report of the committee on strategy for development of tungsten deposit in Rajasthan 1988

Report on evaluation of the dumps of Degana tungsten mine 1990 IBM

Bhatnagar S N 1991 Review of ore resources and exploration strategy for Degana tungsten mine, Hindustan Zinc Ltd.

Roy R N 1991 Report on mineralogical and petrological studies on samples from Degana tungsten mine, Hindustan Zinc Ltd.

TRDDC Report 1991 Development of selective flocculation technology for recovery of tungsten value from slimes

IBM/AJM/R 1-193 1992 Semi pilot scale beneficiation studies on a very low grade tungsten ore composite sample from Degana mines, Nagaur Dist., Rajasthan

NML/Jamshedpur 1991 lnterim Report No. 6, Beneficiation of tungsten ore in India

Minutes of the 1st meeting of the Project Monitoring Committee for Tungsten Development

Minutes of the 5th PMCTD meeting 1990 